\title{
IL15N72D superagonist/IL15Ro-Fc fusion complex (ALT-803) exhibits anti-metastatic activity in murine breast tumor model
}

\author{
Peter S Kim, Anna R Kwilas', Emily K Jeng², Hing C Wong ${ }^{2}$, Jeffrey Schlom¹, James W Hodge ${ }^{1}$ \\ From 30th Annual Meeting and Associated Programs of the Society for Immunotherapy of Cancer \\ (SITC 2015) \\ National Harbor, MD, USA. 4-8 November 2015
}

Interleukin (IL)-15N72D-superagonist-complexed with IL15R $\alpha$-Fc fusion protein (IL15-SA/IL15R $\alpha-F c$, also known as ALT-803) has been reported to have greater anti-myeloma activity, due to its increased in vivo half-life and unique tissue biodistribution, than native IL-15 alone in murine models. In order to test the anti-tumor efficacy of IL15-SA/IL15R $\alpha-F c$ in a non-hematologic murine cancer model, we examined the monotherapy effect of IL15-SA/IL15R $\alpha$-Fc in non-tumor bearing mice and in the 4T1-breast tumor model. In non-tumor bearing Balb/c mice, IL15-SA/IL15R $\alpha$-Fc (1 $\mu$ g i.p.), a 10-fold increase occurred in NK cells followed by CD8+ T cells (3-fold), both peaking on Day 3 post treatment. In examining NK cell population subsets, the greatest significant change was in high effector (CD11b+, CD27hi) NKs as compared with terminal effector (CD11b+, CD27lo) NKs on Day 3 post IL15-SA/IL15R $\alpha$-Fc-treatment, leading to increased NK function on a per-cell basis. CD8 subset analysis determined that IL15-SA/IL15R $\alpha$-Fc significantly increased IL15-responding, memory (CD122+, CD44+) CD8+ $\mathrm{T}$ cells, in particular those having the innate (NKG2D+, PD1-) phenotype. In 4T1 tumor bearing mice, IL15-SA/ IL15R $\alpha$-Fc induced significant anti-metastatic activity, and thus consequently resulted in a longer median survival of IL15-SA/IL15R $\alpha$-Fc-treated mice following surgical resection of the primary tumor. Finally, T cell depletion revealed that the anti-metastatic property of IL15-SA/ IL15R $\alpha$-Fc was dependent on CD8+ T cells and not CD4+ $\mathrm{T}$ cells. Altogether, these studies showed for the first time that IL15-SA/IL15R $\alpha$-Fc a) promoted the development of high effector NKs, b) enhanced per-cell function of NKs,

${ }^{1}$ National Cancer Institute, National Institutes of Health, Bethesda, MD, USA Full list of author information is available at the end of the article and c) played a vital role in reducing tumor metastasis and ultimately survival.

\section{Authors' details}

${ }^{1}$ National Cancer Institute, National Institutes of Health, Bethesda, MD, USA. ${ }^{2}$ Altor BioScience Corporation, Miramar, FL, USA.

Published: 4 November 2015

doi:10.1186/2051-1426-3-S2-P229

Cite this article as: Kim et al:: IL15N72D superagonist/IL15R $\alpha-F c$ fusion complex (ALT-803) exhibits anti-metastatic activity in murine breast tumor model. Journal for ImmunoTherapy of Cancer 2015 3(Suppl 2):P229.
Submit your next manuscript to BioMed Central and take full advantage of:

- Convenient online submission

- Thorough peer review

- No space constraints or color figure charges

- Immediate publication on acceptance

- Inclusion in PubMed, CAS, Scopus and Google Scholar

- Research which is freely available for redistribution
() Biomed Central 